\title{
PERCEPCIJA EHLI-KITABIJA U TEFSIRU IBNI-AŠURA
}

\section{Sažetak}

Ovom studijom nastojat ín ukazati na kur'anske principe u pogledu sljedbenika Knjige. Muslimani žive u rajednicama sa ljudima koji imaju drugačije svjetonazore; negdje su većina, a negdje su manjina. Kako je počeo $i$ kako se odvijao život $i$ međusobna komunikacija među različitim religijskim zajednicama u vrijeme dolaska posljednje Allahove Knjige, Kur'ana, govori nam sam Kur'an.

Kao dodatni element za bolje raqumijevanje kur'anskog izraza na spomenutu tematiku, pomogli smo se stavovima $i$ mišljenjima jednog savremenog tumača Kur'ana. Ibni-Ašur nam je pomogao da predstavljanje sljedbenika Knjige bude dosta jasnije. Citalac ove studije će se, bar nakratko, zamisliti ili provjeriti svoju raniju spoznaju naslovljene tematike. Vidjet ce se uloga sljedbenika Knjige u zivivotu posljednjeg Poslanika Mubammeda, s.a.v.s., i njibov odnos prema islamu u tom vremenu. To $i$ nama mo:̌e posluriti da, koristeći metode Kur'ana $i$ sunneta, iggradimo ispravan stav u odnosu na Jevreje i kršćane.

Da, to su Allahove riječi u Njegovoj Knjizi. Nije rijedak slučaj da čujemo kako je neko od Jevreja, a pogotovo od kršćana, pribvatio islam. Motiva je mnogo $i$ jako su raznovrsni, sto ukazuje na primamljivost i ljepotu posljednje Allabove Knjige Kur'ana i vjere islama.

Ključne riječi: Kur'an, Ehli-Kitabije, Jevreji i kršćani, islam, Ibni-Ašur, meduvjerski dijalog, Bơ̌ịi kitabi, Bơ̌ịi poslanici, Mubammed, s.a.v.s., vjera, Knjiga.

\section{Uvod}

Knjiga kao pojam nalazi se u rječnicima svih jezika. Knjiga je i najbolji prijatelj čovjeku, kako kaže naša poslovica.

Međutim, kategorija koja se naziva Ehli-Kitabije, sintagma je koja se u našem jeziku prevodi kao sljedbenici Knjige, sinonim je za današnje Jevreje i kršćane. Osnovna razlika u poimanju ove dvije vrste knjiga jeste u njihovim autorima. Svi ljudi mogu da se bave čitanjem, ali sljedbenik

${ }^{1}$ Islamski pedagoški fakultet u Bihaću 
Knjige može biti samo onaj koji čita i slijedi Božiju Knjigu, kao božansku uputu.

Nedavno se pojavila informacija o jednom novom muslimanu, kome je razlog za prihvatanje islama bio ajet s početka sure El-Bekare. Naime, pročitao je: Ovo je Knjiga u koju nema sumnje. Sam je zaključio: Nikada u vivotu nisam imao priliku da citam knjigu od bilo kojeg autora, a da je rekao kako je njegova knjiga čista Istina. A kada tako piše na početku knjige Kur'ana, onda mora da je i njen Autor Istina.

\section{Posljednja Objava}

Allahovom, dž. š., voljom na tlu Arabijskog poluotoka pojavljuje se najsvjetliji lik čovjeka u ljudskoj povijesti. Svakako da ga takvim, još i većim, smatraju svi muslimani svijeta. Muhammed, a.s. - čovjek od krvi i mesa i sa svim životnim potrebama i zahtjevima - biva odabranim poslanikom od Allaha, dž. š., da obavi jednu ogromnu misiju za čovječanstvo.

Rođen je u šestom vijeku, a poslaničku misiju dobiva na početku sedmog vijeka, kroz prve riječi Objave: IKRE - Ǔ̌i, čitaj, studiraj. Desilo se to u ramazanu 610. godine po Isau, a.s., i dostava Objave je trajala naredne 23 godine. Posljednji Allahov poslanik u tom periodu primio je Božansku Objavu - Kur'an, a. š. U širokoj lepezi kur'anskog sadržaja, Allah, dž. š., slao je ajete, svete tekstove Svoje Knjige, u kojoj mudre riječi sadržavaju sva najbitnija pitanja za uređenje svijeta. U toj posljednjoj Allahovoj Objavi nalaze se moralni, zakonodavni, povijesni i svi drugi bitni sadržaji potrebni jednom čovjeku.

Kada kažemo da je Muhammed, a.s., posljednji Božiji poslanik, prihvatamo činjenicu i vjerujemo u sve ranije Njegove poslanike. Isto tako, kada kažemo za Kur'an da je posljednja Božija objava, prihvatamo i vjerujemo u činjenicu da je Allah, dž. š., preko Svojih poslanika i ranije dostavljao objave - Božije knjige. Veoma mnogo je bilo sličnih sadržaja u svim tim objavama, uz još neke određene specifičnosti koje su bile potrebne povijesnom vremenu i prostoru. Osnova svih božanskih objava jeste poziv na vjerovanje u Jednog Stvoritelja svijeta i činjenje dobra na ovome svijetu.

S obzirom na to da je Allah, dž. š., prepustio ljudima da u svojoj slobodi primjenjuju postulate date u Njegovim knjigama, oni su tu slobodu zloupotrijebili, te unosili i neke vlastite intervencije u njih. Iz tog 
razloga, ne možemo reći za ranije Božije objave da ih posjedujemo u originalu, jer su pomiješani tekstovi Objave sa tekstovima kojima je izvor čovjek.

Za posljednju Svoju objavu Uzvišeni Allah je obećanjem rekao da će je On nakon dostave ljudima zasigurno čuvati, tako da joj se nikad neće desiti ono što se desilo ranijim objavama: „Mi, nistinu, Kur'an objavljujemo $i$ zaista ćemo Mi nad njim bdjeti “! ${ }^{2}$ Zato Uzvišeni Allah, dž. š., u Kur'anu spominje Ehli-Kitabije - sljedbenike Knjige i podsjeća ih na njihov originalan sadržaj.

\section{Ehlul-Kitabije}

Pridajući značaj sljedbenicima Knjige, Ehli-Kitabijama, Allah, dž. š., ih pod tim imenom spominje na oko trideset mjesta u Kur'anu. ${ }^{3}$

Ehlul-Kitabijama, sljedbenicima Knjige, smatraju se današnji Jevreji i kršćani, sa svim svojim vjerskim podjelama. Najbliže rečeno, to su oni koji posjeduju posljednje svete knjige pod kur'anskim nazivima: Tevrat, Zebur i Indžil. Pod ovim imenima i sa njihovim izvornim tekstovima - kako su objavljeni - pripadnici islama imaju obavezu da u njih vjeruju kao u sastavni dio vjerske obaveze.

$\mathrm{S}$ druge strane, muslimani nisu u obavezi da apsolutno vjeruju u svete knjige Jevreja i kršćana zbog njihove intervencije i miješanja Božijeg Teksta i tekstova kojima pojava Kur'ana označava novu Božiju intervenciju u zaštiti Njegovog izvornog teksta.

Tokom samog perioda objave Kur'ana i poslanstva Muhammeda, s.a.v.s., ukazivano je na neke anomalije ljudi koji su se uplitali i mijenjali pojedine Božanske poruke i odredbe. ${ }^{4}$ Međutim, ljudskih intervencija u sadržaju Božijih tekstova je bilo i ranije, pa i nakon završetka misije posljednjeg Allahovog poslanika, Muhammeda, s.a.v.s.

Nakon dovršetka posljednje objave Kur'ana, a. š., islamski učenjaci su davali komentare i pojašnjenja za pojedine ajete koji govore o Ehli-

\footnotetext{
${ }^{2}$ El-Hidžr, 9.

3 Tačnije, Ehlul-Kitabije se spominju na 31 mjestu i još jednom u izrazu Ehlu-l-Indřil; vidi: M. F. Abdulbaki, Mu'džemul-mufehres lielfazil-Kur'anil-kerim, str. 117 i 783.

4 Poznat je slučaj Jevreja koji su rukama prekrivali Toru u kojoj je naznačena vrsta kazne za blud. Vidi: Sabihul-Muslim, Muslimova zbirka hadisa - sažetak, str. 452., br. 1040 .
} 
Kitabijama. Svim tumačima Kur'ana nije promaklo da u svojim tefsirima daju svoja pojašnjenja i viđenja realnog stanja i odnosa sljedbenika Knjige prema drugima.

U ovom radu iznijet ćemo poglede na ovu tematiku kroz knjige teksta Ibn-Ašura. ${ }^{5}$

On je svoje djelo nazvao Tefsirut-tahriri vet-tenviri. S obzirom na to da je autor živio i djelovao u drugoj polovici dvadesetog vijeka, možemo reći da je i naš savremenik. S druge strane, živio je u Tunisu - sredini u kojoj živi, iako kao manjina, kršćanski i jevrejski narod sa svojim bogomoljama. Ti navedeni podaci su me ponukali da u slijedećim redovima predstavim i ukažem na načine na koje ih autor predstavlja.

\section{Osvrt Ibn-Ašura na prijašnje objave}

Uzvišeni Allah u u Časnom Kur'anu kaže:

„Mnogi sljedbenici Knjige jedva bi dočekali da vas, pošto ste postali vjernici, vrate u nevjernike, iz, lične zlobe svoje, iako im je Istina poznata; ali, vi oprostite $i$ preko toga pređite dok. Allah Svoju odluku ne donese. Allah, zaista sve može. " 6

Pojava Nove Objave, Kur'ani-Kerima, izazvala je kod sljedbenika ranijih objava jednu vrstu nelagodnosti i nevjerice. Nažalost, većina nije mogla prihvatiti činjenicu da je stigao Posljednji Allahov poslanik Muhammed, s.a.v.s., a s njim i posljednja objava.

$\mathrm{S}$ obzirom na to da su u početku većina onih koji su priznavali Muhammeda, s.a.v.s., za poslanika, ranije bili mnogobošci (mušrici), sljedbenici ranijih knjiga iskazuju želju da bi ih radije ponovo vidjeli kao mušrike, nego kao muslimane. Ovdje je upotrijebljena arapska riječ hased u značenju zavisti koje kitabije nose u sebi. Svakako je nepobitna činjenica da zavidnik može biti samo osoba koja je inferiorna, slabija ili manje važna u odnosu na osobu prema kojoj je zavist usmjerena. Zavidnici zavide samo onima koji su bolji od njih ili, pak, posjeduju nešto bolje.

5 Muhammed Tahir Ibn-Ašur je jedan od najvećih alima našeg vijeka. Poznati je malikijski pravnik i nekadašnji rektor Univerziteta Zejtuna u Tunisu. Napisao je više djela od kojih su najpoznatiji tefisr Et-Tahriru vet-tenvir i Mekasiduš-šeri'ah. Na pisanju svoga tefsira proveo je 39 godina. Umro je 1972. godine u Tunisu.

${ }^{6}$ El-Bekara, 109. 
Ibni-Ašur navodi činjenicu da su svećenici iz reda Jevreja i kršćana, sa svojim učenjacima, ulagali veliki trud na prostoru gdje su živjeli Arapi pozivajući ih u svoju vjeru, ali su imali vrlo malo uspjeha. Zato su se čudili uspjehu Muhammeda, s.a.v.s., koji ih je pozivao u čisti monoteizam - vjeru u Jednog Boga - a u isto vrijeme pozivao je i na poštivanje poslanika Musaa, a.s., i Isaa, a.s., koji su ranije dolazili sa Božijim kitabima. ${ }^{7}$

Ibni-Ašur, također, razlaže i analizira činjenicu da je Allah, dž. š., rekao kako Ehli-Kitabije znaju $i$ da im je potpuno jasna Istina na kojoj se nalaze muslimani, te da su sa tom činjenicom najbolje upoznati najučeniji sljedbenici Knjige. ${ }^{8}$

I pored zlobe i zavisti u dušama Jevreja i kršćana prema muslimanima, Allah, dž. š., u formi imperativa traži od muslimana da iskažu spremnost na toleranciju i oprost, te da se osvetnički ne ponašaju prema njima. ${ }^{9}$

U konačnici, Allah, dž. š., je taj koji će presuditi, pogotovo onima koji pređu granicu zavisti i izvrše neprijateljski fizički akt protiv pripadnika islama. Takav je slučaj bio sa nekoliko plemena koji su pripadali jevrejskoj zajednici (Benu-Nadir i Benu-Kurejza). ${ }^{10}$

Kur'anski tekst navodi dalje kako se, nakon zavisti iskazanog prema muslimanima, spas i Džennet, po njima, može naći samo u okvirima „njihovog“ učenja, pa kaže: „Oni govore da će u Dřennet ući samo Jevreji, odnosno samo kršćani. - To su puste želje njihove! - Ti reci: Dokaz svoj dajte ako je istina to što govorite!" ${ }^{11}$ Svojatajući i rezervišući Džennet (Raj) samo za sebe, oni kažu da će svi drugi biti kažnjeni i neće im biti spasa. $\mathrm{Na}$ ovaj isključivi stav po tom pitanju, nailazimo i na drugom mjestu u Kur'anu gdje se kaže: „A nije tako! Onoga ko se bude Allabu pokoravao i uz to dobra djela činio, toga čeka nagrada kod Gospodara njegova, takvi se néce ničega bojati i ni za čm né́e tugovati. "12

Tonući dublje, u svom isključivom stavu po ovom pitanju, EhliKitabije i sami se međusobno spore ko ima pravo, tj. nije im dovoljna

\footnotetext{
7 Vidi; Muhammed Tahir, Ibn-Ašur, Tefsirut-tahriri vet-tenviri, 1/669.

${ }^{8}$ Ibid., $1 / 670$.

${ }^{9}$ Ibid., $1 / 671$.

10 Ibid.

11 El-Bekare, 111.

12 El-Bekare, 112.
} 
zajednička zavist prema muslimanima, nego žele istaći sebe ispred drugih. Kur'an kaže: „Jevreji govore: „Kršćani nisu na pravom putu!", a kršćani vele: "Jevreji nisu na pravom putu!" - a oni ř̈taju Knjigu. Tako, slično kao oni, govore i oni koji ne znaju. Allah će im na Sudnjem danu presuditi o onome u čemu se oni ne slą̆u. "13

Ibni-Ašur navodi događaj iz vremena Poslanika, s.a.v.s., kojega je posjetila jedna veća delegacija kršćana među kojima je bilo i svećenika. Kada su to primijetili Jevreji Medine, i oni dođoše i vrlo brzo se međusobno počeše svađati pred Poslanikom, s.a.v.s. Bilo je tu psovki i teških, uvredljivih riječi koje su uputili jedni drugima, pa čak su se vrijeđale i suprotne vjerske svetinje. ${ }^{14}$

Kada se suprotstave dva stava po jednom određenom pitanju, kakav je slučaj sukoba između Jevreja i kršćana, realno je to da jedni od njih nisu upravu. Prema islamskom načinu prosuđivanja problema koji su od strane sljedbenika Knjige izneseni, ne daje se za pravo ni jednima ni drugima, a razlog tome leži u činjenici da su se i jedni i drugi odvojili od autentičnih i izvornih učenja, koja su im dostavljali Allahovi poslanici (Musa i Isa, a.s.).

U vremenu objave Tevrata i za života Musaa, a.s., Uzvišeni Allah kaže: „Mi smo objavili Tevrat, u kome je uputstvo $i$ svjetlo. Po njemu su Jevrejima sudili vjerovjesnici, koji su bili Allahu poslušni i čestiti ljudi, i učeni, od kojïh je trað̌eno da čuvaju Allahovu knjigu, i oni su nad njom bdjeli.

Zato se, kada budete sudili, ne bojte ljudi, već se bojte Mene, i ne zamjenjujte riječi Moje za nešto što malo vrijedi! A oni koji ne sude prema onome što je Allah objavio, oni su pravi nevjernici. " 15

Isto tako, za vrijeme objave Indžila, za života Isaa, a.s., imamo pohvalni izraz za sadržaj Objave: „Poslije njĭh smo Isaa, sina Merjemina, poslali, koji je priznavao Tevrat prije njega objavljen, a njemu smo dali Indřil, u kome je bilo uputstvo $i$ svjetlo, $i$ da potvrdi Tevrat, prije njega objavljen, u kome je takoder bilo uputstvo i pouka onima koji su se Allaha bojali, i sljedbenicima Inď̃ila smo bili naredili da sude prema onome sto je Allah objavio u njemu. Oni koji nisu sudili prema onome što je Allab objavio - pravi su grješnici. " 16

\footnotetext{
13 El-Bekare, 113.

14 Vidi; Ibn-Ašur: 1/675, 676

15 El-Maide, 44.

${ }^{16}$ El-Maide, 46-47.
} 
U drugom dijelu citiranog ajeta želi se kazati da su mušrici (idolopoklonici) još i gori. Oni ne samo da ne priznaju Jevreje i kršćane, nego ni i muslimane zbog određenih međusobnih sličnosti. ${ }^{17}$

Jedino „opravdanje“ za sebe mogu imati u tome što ih je Allah, dž. š., nazvao onima koji nemaju znanja (neznalicama).

Kada je riječ o zajedničkom stavu sljedbenika Knjige prema muslimanima, Uzvišeni kaže: „Ni Jevreji, ni kršćani neće biti tobom zadovoljni sve dok ne pribvatis vjeru njibovu. Reci: „Allabov put je jedini pravi put!" A ako bi se ti poveo za řeljama njihovim, nakon Objave koja ti dolari, od Allaha te niko ne bi mogao zaštititi niti odbraniti." 18

U arapskom tekstu je upotrijebljena riječ len koja ima značenje čvrste i apsolutne negacije za radnju (glagol) koji se odvija u budućnosti. To znači da muslimani moraju biti svjesni istinitosti Allahovih riječi koje ukazuju na to da nikada ni Jevreji ni kršćani neće biti zadovoljni sa njima dok ne napuste islam i postanu jedni od njih. Važno je to upozorenje sa akaidsko-ideološke strane, što znači da se ne mogu neke vrste ovozemaljskih poslova odvijati sa osobama koje imaju drugačiji svjetonazor.

U kur'anskoj suri Ali-Imran nailazimo na ajete koji ukazuju na to da postoje određena učenja koja su prožimala i ranije Božije knjige, kao i Kur'an. Tako se u 64. ajetu spomenute sure kaže: „Reci: „O sljedbenici Knjige, dođite da se okupimo oko jedne riječi i nama i vama zajednicke: da se nikome osim Allabu ne klanjamo, da nikoga Njemu ravnim ne smatramo $i$ da jedni druge, pored Allaha, bogovima ne držimo!“ Pa ako oni ne pristanu, vi recite: „Budite svjedoci da smo mi muslimani! ‘d9

\section{Zajednički elementi na koje Kur'an poziva:}

a) čisti monoteizam - Bog je Jedan,

b) odbacivanje bilo kakvog božanstva mimo Njega - Allaha,

c) zabrana da se ljudi podižu na stepen božanstva (svetosti).

Prve dvije stavke se nalaze i u temeljnim učenjima sljedbenika Knjige - u sadržaju Deset zapovijedi. Treća stavka je upozorenje na to da

\footnotetext{
17 Vidi; Ibn-Ašur: 1/677

${ }^{18}$ El-Bekara, 120.

19 Ali-Imran, 64.
} 
se ljudsko biće (stvorenje) ne može dići na stepen božanstva, pa makar to bio i Isa, a.s. ${ }^{20}$

Da, i muslimani kao kršćani vjeruju da je Isa, a.s., došao na ovaj svijet bezgrješnim začećem njegove časne majke Merjeme (Marije), ali to ne znači da mu se mogu dati božanska svojstva. Ako već želimo isticati čudan dolazak na ovaj svijet, onda je pojava Adema, a.s. (Adama) svakako još neobičnija. Došao je na ovaj svijet i bez oca i bez majke, ali ga niko nikada nije nazvao Bogom ili Božijim sinom.

Allah, dž. š., je rekao: „Isaov slučaj je u Allaha isti kao i slučaj Ademov: od zemlje ga je stvorio, a zatim rekao: „Budi!“- $i$ on bi." 21

Vraćajući se pozivu na zajedničke elemente u svim Božijim knjigama, naći ćemo mnogo toga što je zajedničko, čak i više nego što je to u 64. ajetu sure Ali-Imran spomenuto.

Podsjetimo se i jedne mudre odluke bivšeg Visokog predstavnika za Bosnu i Hercegovinu, koji je imao značajnu ulogu da, nakon rata u našoj zemlji, iznađe neka zajednička rješenja. Bio je to Portugalac Carlos Vestendorp koji je, umjesto nacionalnih simbola u zastavama Bošnjaka, Srba i Hrvata, ponudio upotrebu zastave koja je od njegovog vremena postala zajednička zastava $\mathrm{BiH}$ u današnjem obliku.

Kada je riječ o registraciji vozila u $\mathrm{BiH}$, imali smo priliku gledati nacionalna obilježja spomenutih naroda, pa na tablicama vidjeti ljiljane, četiri ćirilična $s$ i šahovnicu.

U zamjenu za ta tri oblika, spomenuti Visoki predstavnik je iznašao prihvatljivo rješenje za sve. Uzeo je zajednička slova u ćirilici i latinici i, tako u kombinaciji sa arapskim brojevima, dobivamo jedinstvene tablice u BiH.

Latinična slova:

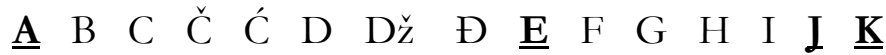

$\begin{array}{lllllllllllllll}\mathrm{L} & \mathrm{Lj} & \underline{\mathbf{M}} & \mathrm{N} & \mathrm{Nj} & \mathrm{O} & \mathrm{P} & \mathrm{R} & \mathrm{S} & \check{S} & \underline{\mathbf{T}} & \mathrm{U} & \mathrm{V} & \mathrm{Z} & \check{Z}\end{array}$

Cirilična slova:
$\begin{array}{lllllllllllllll}\underline{\mathbf{A}} & Б & В & \Gamma & \boldsymbol{A} & \text { Ђ } & \underline{\mathbf{E}} & Ж & 3 & И & \mathbf{J} & \underline{\mathbf{K}} & \Lambda & \Lambda & \underline{\mathbf{M}}\end{array}$

${ }^{20}$ Vidi; Ibni-Ašur, 3/268.

21 Ali-Imran, 59. 


\section{$\begin{array}{llllllllllllllll}\mathrm{H} & Њ & \mathrm{O} & \Pi & \mathrm{P} & \mathrm{C} & \underline{\mathbf{T}} & \mathrm{h} & \mathrm{У} & \Phi & \mathrm{X} & Ц & Ч & \amalg & Ш\end{array}$}

Izgleda kao da je Visoki predstavnik znao za spomenuti kur'anski ajet $\mathrm{i}$ „oko nama zajedničkih stvari“ pronašao ono što je svima u $\mathrm{BiH}$ zajedničko i došao do sretnog rješenja za sve. Tako npr. imamo tablicu na vozilu 416 - M - 975 iz čega se ne može „prepoznati“ da li je vlasnik vozila Bošnjak, Srbin ili Hrvat. Takvim rješenjem je zadovoljena forma koja ima veoma bitnu ulogu u našem društvu.

Vraćajući se na ideološko polje i razmatrajući djelovanje sljedbenika Knjige, vidjet ćemo kako ih Uzvišeni Allah opisuje u slijedećem ajetu u kojem kaže: „A jest! Samo onoga ko obavezu svoju ispuni $i$ grijeha se kloni Allah voli. "22

Ibni-Ašur u ovom tefsiru pojašnjava kako postoje dvije grupacije Kitabija - jedni koji stoje iza zadate riječi i drugi na koje se ne može računati. Kao primjer pozitivnog Kitabije navodi se Abdullah b. Selem, a kao negativac je spomenut Finhas b. Azurae, a oba su bili pripadnici medinskih Jevreja. ${ }^{23}$ Svojom intervencijom Jevreji su postavili tekst $u$ svoju svetu knjigu u kojoj se na različite načine tretiraju ljudska prava. Tako se obaveza Jevreja prema Jevreju mora ispoštovati, dok obaveza Jevreja prema nejevreju ne mora. Međusobna dugovanja Jevreja se mogu otpisati i oprostiti, dok Jevrej ne smije da otpisuje dug nejevreju. ${ }^{24}$

Ibni-Ašur također navodi riječi Ibni-Kelbija o stavovima Jevreja, pa kaže: „Sva imovina je bila naša, tako da sve što je u rukama Arapa pripada nama. Oni su to uzeli od nas silom, pa ćemo i mi uzimati od njih. " 25

U suri Ali-Imran u 78. ajetu je izrečena kritika Uzvišenog Allaha upućena sljedbenicima Knjige i upozorenje da ne lažu na Boga - da im je On dozvolio da se tako dvojako ponašaju: „Neki od njïh wijaju jezike svoje rítajuci Knjigu da biste vi pomislili da je to iz. Knjige, a to nije iz. Knjige, i govore: "To je od Allaha!" - a to nije od Allaha, i o Allabu svjesno govore laži. "

U 98. i 99. ajetu spomenute sure kaže se: „Reci: „O sljedbenici Knjige, zašto u Allahove dokaz̧ ne vjerujete kad je Allah svjedok svega što radite?" Reci:

\footnotetext{
22 Ali-Imran, 76.

23 Ibni-Ašur: 3/285.

24 Ibid., 3/288.

25 Ibid.
} 
„O sljedbenici Knjige, zašto onoga koji vjeruje - od Allabove vjere odvraćate, nastojeći da je krivom prikažete, a znate da je istina?" A Allah motri na ono što radite!"26

I ove riječi Uzvišenog su riječi upozorenja Ehli-Kitabijama - da ne poriču Allahove dokaze, te da ne odvraćaju s Njegovog puta, jer dobro im je poznato iz ranijih knjiga da je Bogu sve poznato i da Mu ništa ne može promaći.

U tom pogledu, Ibni-Ašur podsjeća Ehli-Kitabije na činjenicu u koju oni čvrsto vjeruju od ranije, a ona se sastoji od toga da Bog Stvoritelj ima svojstvo da sve vidi i svemu svjedoči. ${ }^{27}$ Stoga, nikada ne trebaju smetnuti sa uma da je Allahu, dž. š., sve poznato.

U 110. ajetu sure Ali-Imran Uzvišeni Allah kaže: „Vi ste narod najbolji od svih koji se ikada pojavio: tră̌ite da se čine dobra djela, a od nevaljalih odvraćate, i u Allaha vjerujete. A kad bi sljedbenici Knjige ispravno vjerovali, bilo bi bolje za njib; ima ih i pravih vjernika, ali, većinom su nevjernici. " 28

Ibni-Ašur smatra da ajet, iako usmjeren na Jevreje i kršćane općenito, prvenstveno aludira na Jevreje. To je iz razloga što je Poslanik, s.a.v.s., dolaskom u Medinu imao priliku daleko više sretati Jevreje, nego kršćane kojima se da'vetski (misionarski) obraćao. Navedenim ajetom im se ukazuje i pruža prilika za njihovu osobnu dobrobit - naravno ukoliko prihvate vjeru islam. S tim u vezi Ibni-Ašur navodi sahih hadis u kome Muhammed, a.s., kaže: „Da su desetorica Jevreja povjerovala u mene, svi bi Jevreji povjerovali u mene. " 29

U tumačenju ovoga hadisa se kaže da ovdje nije riječ o bilo kojoj desetorici Jevreja, nego da se misli na desetak Jevreja od autoriteta - koji bi utjecali na to da $i$ svi ostali postanu muslimani. Jer, zasigurno je daleko veći broj „obicnib" Jevreja pribvatilo islam, od kojih Ibni-Ašur u svome tefsiru navodi i kaže najmanje dvanaest osoba. ${ }^{30}$

Gore citirani ajet je potakao i kršćane iz Nedžrana, te kršćane Abesinije. Zanimljiv je i slučaj Jevreja Muhajrika koji je prvo materijalno

\footnotetext{
26 Ali-imran, 98. i 99.

27 Ibni-Ašur: 4/25.

28 Ali-Imran, 110.

${ }^{29}$ El-Buhari, hadis br. 3941.

${ }^{30}$ Ibni-Ašur: 4/53.
} 
pomagao muslimane, a nakon toga $\mathrm{i}$ islam kao vjeru prihvatio, tako da je djelima i riječima potvrdio svoju vjersku opredijeljenost. ${ }^{31}$

Pogledajmo sada slijedeće ajete $\mathrm{i}$ uočit ćemo značajnu vezu sa ranijim tekstom:

„Ali, nisu svi oni isti. Ima ispravnih sljedbenika Knjige koji po svu noć Allahove ajete citaju i mole se; Oni u Allaha i u onaj svijet vjeruju $i$ trǎ̌e da se cine dobra djela, a od nevaljalih odvraćaju i jedva čekaju da wäine dobročinstvo; oni su čestiti; bilo kakvo dobro da urade, biće za nj nagradeni. - A Allab dobro zna one koji se Njega boje. " 32

Allahu ekber! Koliko li je Uzvišeni Gospodar dobar prema Svojim robovima! On nas obavještava da među sljedbenicima Knjige ima tako dobrih vjernika. Ibni-Ašur podsjeća na moguće činjenice i značajan podatak da su dobri vjernici među Jevrejima prihvatili očekivanja Allahovog poslanika Isaa, a.s., a u isto vrijeme se držali učenja iz Tevrata. Također, po pojavi Muhammeda, s.a.v.s., kao Allahovog poslanika, jedan broj Jevreja, a još veći broj kršćana je priznalo posljednjeg Vjerovjesnika, s.a.v.s. ${ }^{33}$

Nastavljajući pozitivno kazivanje o sljedbenicima Knjige, Uzvišeni kaže: „Ima i sljedbenika Knjige koji vjeruju u Allaba $i$ u ono što se objavljuje vama i u ono sto je objavljeno njima, ponizni su prema Allabu, ne ramjenjuju Allahove riječi za nesto śto malo vrijedi; oni će nagradu od Gospodara njibova dobiti. - Allah će zaista brzo račune svidjeti. " 34

Allahova informacija data u Kur'anu nam govori i o dobrim sljedbenicima Knjige koji, faktički, u svome vjerovanju sliče islamskim vjernicima. Tumačeći ovaj ajet, jedni su mislili da se to odnosi na one koji su nekada bili sljedbenici Knjige, pa prešli na islam, dok drugi smatraju da je riječ zaista o onima koji su uistinu Jevreji i kršćani.

Kao primjer za prve, uzima se Abdullah b. Selam - bivši jevrejski rabin koji je postao musliman. Primjer za drugi stav jeste slučaj abesinskog vladara Nedžašija, koji je bio kršćanin, ali je priznao

\footnotetext{
31 Ibni-Ašur: 4/54.

32 Ali-Imran, 113-115.

33 Ibni-Ašur: 4/57-58.

34 Ali-Imran, 199.
} 
Muhammeda, a.s., i njegovo vjerovjesništvo. Poznato je i to da mu je Poslanik, s.a.v.s., klanjao dženazu u odsustvu. ${ }^{35}$

S obzirom na to da ima i dobrih sljedbenika Knjige i onih koji to nisu, slijedeći ajet poziva na ispravljanje pojedinih postupaka, kao što može biti sakrivanje pojedinih ajeta tekstova Božije objave, pa Gospodar

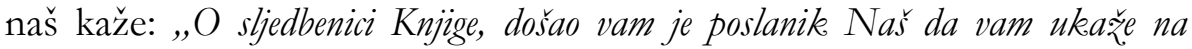
mnogo šta vi iz Knjige krijete, i preko mnogo čega će i preći. A od Allaha vam dolazi svjetlost i Knjïga jasna. "36

Ibni Ašur smatra da se ovdje cilja na one koji su predvodnici Jevreja i kršćana, njihovi svećenici, koji - više svjesno, nego nesvjesnoprikrivaju dijelove božanske upute. Zato je pojava Muhammeda, a.s., i Kur'ana način da se ispravi ono što je pogrešno učeno kod Kitabija uz spremnost da im se oprosti mnogo toga što su učinili. ${ }^{37}$

U tom kontekstu možemo dodati i slijedeći ajet, gdje Uzvišeni kaže: „A da sljedbenici Knjige vjeruju i grijeha se čvaju, Mi bismo prešli preko

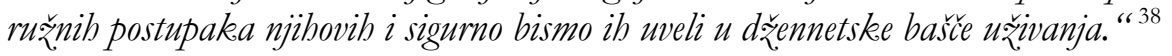

Opraštanje i džennetska nagrada su rezultat ispravne vjere Kitabija i nečinjenje grijeha, a temeljni dio leži u vjerovanju u poslanstvo Muhammeda, a.s. ${ }^{39}$

Koliko god često bili spominjani Jevreji i kršćani pod jednim zajedničkim imenom - Ehli-Kitabijama, u Kur'anu ima i situacija kada su dati različiti opisi jednih i drugih. Tako Uzvišeni kaže: „Ti ćeš sigurno naći da su vjernicima najljuci neprijatelji Jevreji i mnogobošci; i svakako ćeš naći da su vjernicima najbliži prijatelji oni koji govore: „Mi smo kršćani", zato što medu njima ima svećenika $i$ monaha $i$ sto se oni ne obole. Kada slušaju ono što se objavljuje Poslaniku, vidiš kako im liju suze iz ořju, jer znaju da je to Istina, pa govore:

„Gospodaru naš, mi vjerujemo, pa upiši i nas među one koji su posvjedocili. Zašto da ne vjerujemo u Allaha i u Istinu koja nam dolari, kada jedva čekamo da $i$ nas Gospodar naš uvede sa ljudima dobrim. ${ }^{*}$

\footnotetext{
35 Ibni-Ašur: 4/207.

36 El-Maide, 15.

${ }^{37}$ Ibni-Ašur: 7/150.

38 El-Maide, 65.

39 Ibni-Ašur: 7/252.

${ }^{40}$ El-Maide, 82-84.
} 
Jevreji i mnogobošci su svrstani u zajedničku skupinu zbog njihove pojačane mržnje prema Muhammedu, s.a.v.s., nakon već ranijeg napada na Isaa, a.s. Međutim, kršćani pojavom Isaa, a.s., postaju, kako povijesno tako i ideološki, nešto bliži muslimanima, te ne čudi što je više kršćana nego Jevreja koji su prihvatili islam.

Ibni-Ašur smatra da, kada je riječ o „bliskosti“ kršćana sa muslimanima, kršćani su prvi koji se prijateljski odnose prema pripadnicima islama. ${ }^{41}$ Svakako je divno čuti da u redovima kršćana, a pogotovo svećenika, ima onih koji iskazuju ovosvjetsku skromnost, a ne oholost - osobinu koja nikome nije draga. Koristeći informacije od ranijih mufesira, Ibni-Ašur navodi i mišljenje kako se spomenuti ajeti odnose na šezdeset i dva svećenika koji su djelovali na prostoru Abesinije i Šama - te su za života Muhammeda, s.a.v.s., prihvatili islam. ${ }^{42}$

Allah, dž.š., je dao opću uputu vjernicima da prilikom vođenja dijaloga sa drugima vode računa da to bude na najbolji način, a posebnu napomenu da se tako lijepo ophodimo sa sljedbenicima Knjige. Tako Uzvišeni kaže: „I sa sljedbenicima Knjige raspravljajte na najjeptši način, - ne sa onima medu njima koji su nepravedni - i recite: „,Mi vjernjemo u ono što se objavljuje nama $i$ u ono što je objarljeno vama, a naš Bog i vaš Bog jeste - jedan, i mi se Njemu pokoravamo. " 43

Ovdje izražena posebnost u vođenju lijepog dijaloga sa sljedbenicima Knjige je, po mišljenju Ibni-Ašura, između ostalog i zbog toga što je Autor svih knjiga Jedan. On, Jedan i Jedini, želi da su odnosi među svima koji poštuju Božije objave, puni međusobne bliskosti. ${ }^{44}$

Izuzetak iz vođenja prijatnog dijaloga i diskusija su oni koji čine nepravdu (u originalnom arapskom tekstu zulum), što bi vodilo neuspjehu dijaloga. Nepravedni (zalimi) ne žele slušati drugačija mišljenja, jer je u biti takvih osoba apsolutna žlja za dominacijom, bez obzira da li bili u pravu ili ne.

\footnotetext{
${ }^{41}$ Ibni-Ašur: $7 / 6$.

42 Ibni-Ašur: 7/9.

${ }^{43}$ El-Ankebut: 46.

44 Ibni-Ašur: 21/7.
} 


\section{Zaključak}

Rezimirajući gore navedeno, možemo reći da nam Allah, dž. š., daje uputstva kako i sa kime voditi dijalog. Na životnim stazama ljudi su potrebni jedni drugima - vođenje dijaloga je nešto bez čega nema pravog suživota. Držimo li se Allahovih uputa, bit ćemo sigurni da nećemo pogriješiti.

Korisno je da na kraju puta rezimiramo osnovnu viziju koja predstavlja osvjetljavanje i razumijevanje krize ummeta, te podcrtavanje elemenata koji nedostaju u projektima dodirnih i sličnih tema.

Islamski ummet nosi misiju upute $\mathrm{i}$ svjetla. $\mathrm{U}$ prošlosti je taj ummet izvršio korekciju toka ljudske civilizacije i uzdigao je na najviše visine moralnosti, naučnosti i univerzalnosti dajući joj polazišta koja stoje iza svih dostignuća savremenog dijaloga. Mora se ponovo vratiti islamska civilizacijska vizija bazirana na vjeri u Jednog Boga, te civilizacijskoj kreativnosti razgovora u kojima neće biti laži niti ponižavanja onog drugog.

Zahtjev za takvim dijalogom izveden je iz same naravi islama i njegova učenja o Jednome Bogu (et-tawbid), jer je to temeljni nalog koji je muslimanima posredovan Božijom objavom, gdje Uzvišeni Allah poziva sljedbenike Knjige da se okupe oko jedne riječi zajedničke i jednima i drugima: da se nikome osim Allahu ne klanjaju, da nikoga Njemu ravnim ne smatraju i da jedni druge, pored Boga, bogovima ne drže. Svetost je jedna, religija je jedna, ali su raznoliki putevi njezinoga zahvata u mišljenju, jeziku i vjerskoj praksi, a Allah će iz svakoga naroda uzeti svjedoka, jer je On stvorio za svaki narod njegov zakon i njegov put. Međutim, spomenuto načelo tradicionalne religijske metafizike na kojem i islam $\mathrm{i}$ kršćanstvo zasnivaju svoje učenje o poštivanju religijskih sloboda drugih tokom povijesti dobivat će, vrlo često, suprotna značenja.

Muslimanima i kršćanima Božanske poruke su zajedničke od Adema, Nuha, Ibrahima, Musaa, Isaa i Muhammeda, s.a.v.s., te je nepoštivanje bilo kojeg od Božijih vjerovjesnika nepoštivanje Božanske objave.

Molimo Uzvišenog Allaha da nam na pomoći bude i da poveća međusobno razumijevanje. 


\section{Literatura:}

1. Besim Korkut, Kur'an s prijevodom značenja na bosanski jezik

2. Muhammed Fuad Abdulbaki, Mu'džemul-mufehres lielfaz̧il-Kur'anil-kerim, Darul-hadis, Kairo, 1996.

3. Muhammed Tahir Ibn-Ašur, Tefsirut-tahriri vet-tenviri, Darut-tunisijje linnešr, Tunis, 1984.

4. Muhammed b. Ismail el-Buhari, Sabihul-Bubari, grupa prevodilaca, Sarajevo, 1430.h.g./2009.

5. Muslim, Sahihul-Muslim, Muslimova zbirka hadisa - sažetak, grupa prevodilaca, ElKalem, Sarajevo, 2004. 
Izet Terzic, PhD

\section{PERCEPTION OF THE AHL AL-KITAB IN THE TAFSIR OF IBN ASHUR}

\section{ABSTRACT}

In this interesting study, I will try to point out the Qur'anic principles regarding the People of the Book. Muslims live in communities with people who have different worldviews; somewhere as a majority, and in some places as a minority. The Qur'an tells us how the life and mutual communication between the various religious communities started and how it unfolded during the Revelation of the final Book of Allah.

As an additional element for the better understanding of the Qur'anic expression on the mentioned topic, we used statements and opinions of one contemporary Qur'anic scholar. Ibn Ashur has helped us to present People of the Book in a lot clearer manner. The readers of this study will certainly reflect or check their previous knowledge of the addressed topics. This article describes the role of the People of the Book in the life of the last Prophet Muhammad, peace be upon him, and their relationship to Islam at that time. This may belp us to build the correct position in relation to the Jews and Christians by using the methods of the Qur'an and Sunnah.

Yes, these are the words of Allah in His Book. It is not uncommon to hear that some of the Jews, and especially Christians, accepted Islam. There are many motives and they are very diverse, which indicates the lure and beauty of the Allab's final Book, the Qur'an and the religion of Islam.

KEY WORDS: Qur'an, Abl Al-Kitab, Jews and Christians, Islam, IbnAshur, interfaith dialogue, The Books of God, The prophets of God, Muhammad, Faith, The Book 
الأستاذ الدكتور عزت ترزيتش

أهل الكتاب في تفسير ابن عاشور

\section{الخلاصية}

من خلال هذه الدراسة الممتعة سأحاول أن أشير إلى مبادئ قرآنية تتعلق بأهل

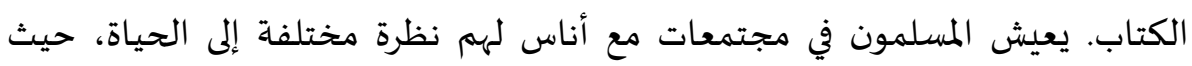

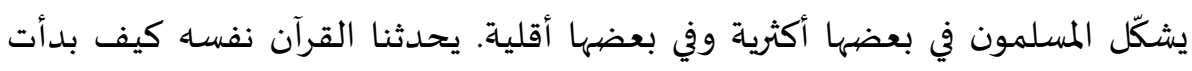

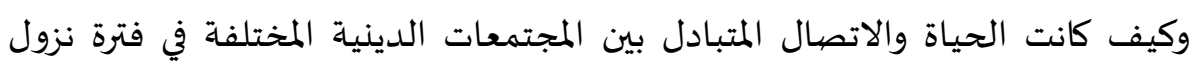
القرآن الكريهم.

لكي نفهم القرآن الكريم بشكل أفضل حول هذا الموضوع من خلال عنصر

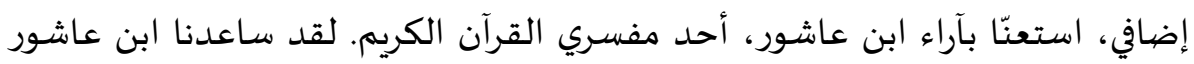

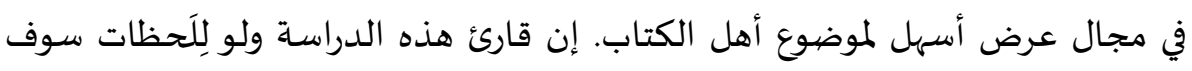

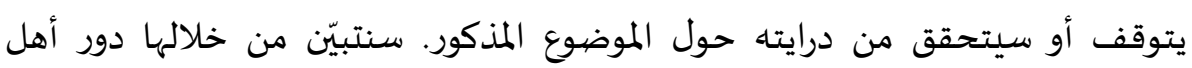

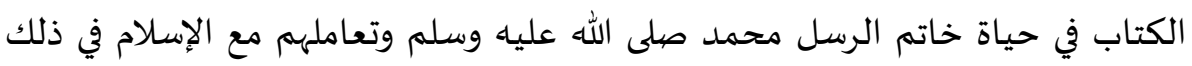

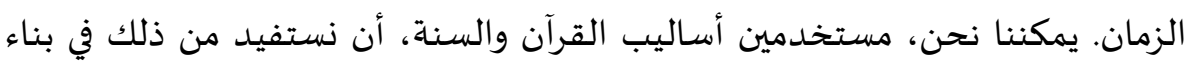
تصور صحيح تجاه اليهود والنصارى.

نعم، تلك كلمات الله في كتابه. ليس حدثاً منعزلاً أن نسمع كيف أن الن بعض اليهود الهيا

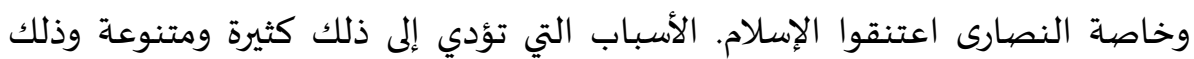

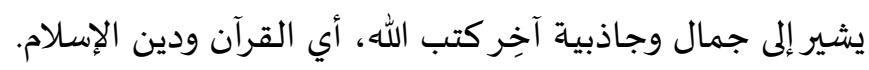

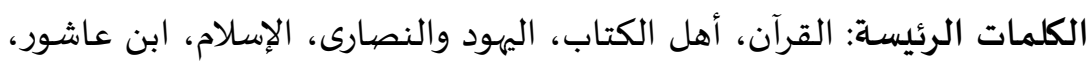

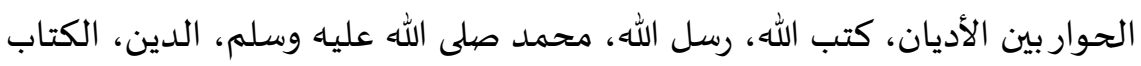

